\title{
Spring 1996
}

Number 3: Volume 1

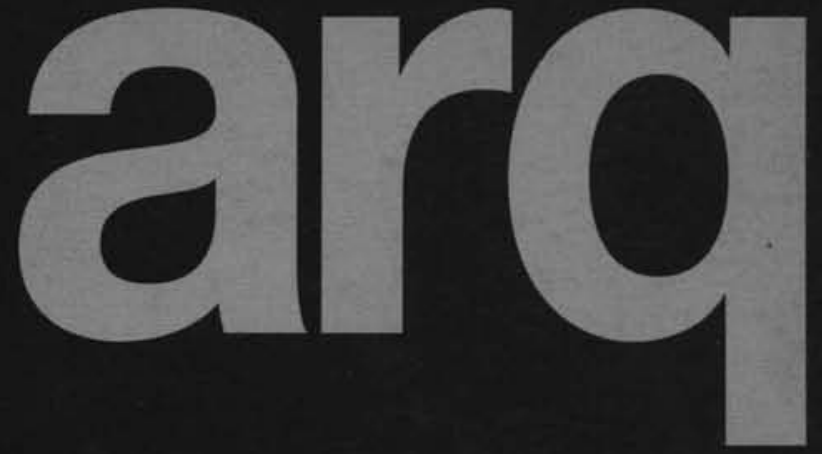

architectural research quarterly:

an international forum for knowledge and ideas 
Editor Peter Carolin

University of Cambridge Department

of Architecture

1 Scroope Terrace

Cambridge CB2 1PX

England

Tel +44 (0) $1223332958 / 9$

Fax +44 (0) 1223332960

e-mail pc207@hermes.cam.ac.uk

Initiating Editorial Board

Bob Allies, Allies and Morrison, London, England

John Berry, Ove Arup and Partners, London,

England

Florian Beigel, Architecture Research Unit, University

of North London, England

Peter Blundell Jones. School of Architectural

Studies, University of Sheffield, England

Dean Hawkes, Welsh School of Architecture,

University of Wales College of Cardiff, Wales

M. J. Long, Long and Kentish, London, England

Sergio Los, IUAV, Venice, Italy

John Macarthur, Department of Architecture

University of Queensland, St. Lucia, Australia

William Mitchell, MIT, Cambridge, Massachusetts.

USA

Juhani Pallasmaa, Otaniemi University, Helsinki,

Finland

Roderigo Perez d'Arce, The Catholic University.

Santiago, Chile

Sam Price, Price and Myers, London, England

Paul Richens, Department of Architecture, University

of Cambridge, England

Julian Roberts, University of Munich, Germany

Andrew Saint, University of Cambridge, England

Phillp Tabor, Bartlett School of Architecture, Building.

Environmental Design and Planning, University

College, London, England

Robert Tavernor, School of Architecture and Civi

Engineering, University of Bath. England

Mark Whitby, Whitby and Bird, London, England

John Worthington, Institute of Advanced

Architectural Studies, University of York, England

arq (Architectural Research Quarterty) is published four times a year by Emap Construct, 151 Rosebery Avenue, London EC1R 4QX, England.

Tel +44 (0) 1715056725

Fax +44 (0) 1715056701
Annual Subscription

Special launch rates (for 4 issues)

Personal rates

$£ 45$ (europe), $£ 55$ (rest of wortd), $\$ 70$ (Americas).

Institutional rates

L89 (Europe), $£ 99$ (rest of world) and $\$ 110$

(Americas).

Send orders with cheque payable to Emap Business

Communications or with credit card accoun

details to:

arq subscriptions

Emap Construct

151 Rosebery Avenue

London EC1R 4QX

England

Tel +44 (0) 1715056616

Fax +44 (0) 1715056610

e-mail mikea@construct.emap.co.uk

Laison Editor Jane Taylor

Art Editor Terry Howe

Circulation/Marketing Manager Mike Aplin

Marketing Director Rowan Crowley

Publishing Director Peter Davey

Managing Director Tim Brooks

Reproduction by ITM Graphics, London

Printed in the UK by Cradley Print L to

arq (Architectural Research Quarterly) is published by

Emap Construct, a part of

Emap Business Communications Limited,

151 Rosebery Avenue

London EC1R 4QX

An Emap Business Publication

Copyright 1996

ISSN 1359-1355 

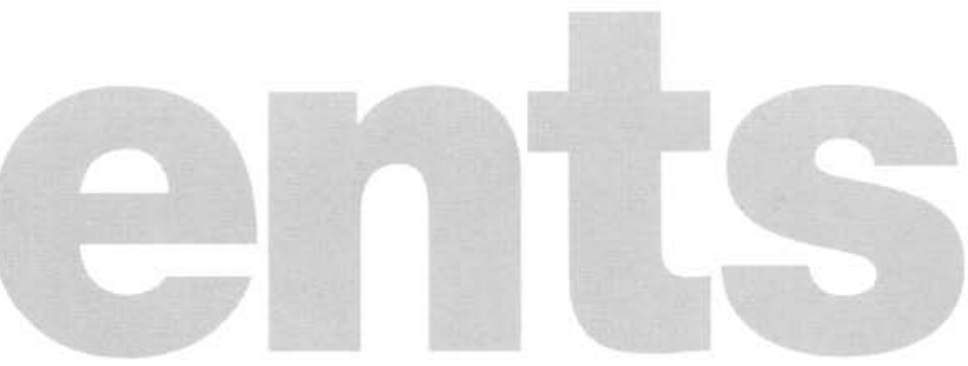

leader

Building on experience

4

letters

The two Scharouns

6

issues

Architecture: functional approach or the case for user

8

research

William Fawcett

design

Building constructs: Richard Murphy Architects Charles Rattray

documents

Jan Gezelius 'A springboard to something better...'

theory

C. R. Mackintosh: the symbolic geometry of The Hill House

environment Eleanor Gregh

construction

Climatic responsive atrium design in Europe

Dennis Ho

Cantilevered staircases

reviews

$S, M, L, X L$ (Small, Medium, Large, Extra Large) reviewed by Florian Beigel and Irénée Scalbert The Other Tradition of Modern Architecture: The Uncompleted Project reviewed by Julian Roberts Sources of Architectural Form: a Critical History of Western Design Theory reviewed by Nicholas Ray The Environmental Tradition: Studies in the Architecture of Environment reviewed by Max Fordham 